\title{
Chemical Ecology of Multitrophic Microbial Interactions: Plants, Insects, Microbes and the Metabolites that Connect Them
}

\author{
Jared G. Ali ${ }^{1} \cdot$ C. L. Casteel ${ }^{2} \cdot$ K. E. Mauck ${ }^{3} \cdot$ O. Trase ${ }^{1}$ \\ Published online: 10 August 2020 \\ (C) Springer Science+Business Media, LLC, part of Springer Nature 2020
}

A major goal of chemical ecology is to understand the ecological function and evolutionary significance of secondary metabolites. Over the last three billion years, microorganisms have interacted and coevolved with each other, and, more recently, with plants and insects. One consequence of these interactions has been an expansion of metabolic capabilities for the players involved. Microorganisms synthesize, convert, concentrate, detoxify, and utilize nutrients and secondary metabolites in diverse ways. This has allowed microorganisms to colonize nearly every niche possible, including the surfaces and internal tissues of other organisms. For example, insects and plants depend on mutualistic microorganisms for nutrient acquisition (Hansen et al. 2020) while simultaneously deploying defenses, such as antimicrobial metabolites (Gross et al. 2010), to protect themselves from microbial parasites and pathogens (Gerardo et al. 2010; Gross et al. 2010). The associations among microbes, plants, and insects have driven the evolution of numerous secondary metabolites, which we are just now beginning to explore.

In 1991 Barbosa, Krischik, and Jones proposed that microorganisms have two major impacts on plant and insect hosts and the interactions they share. First, microbe mediation of metabolism can change the suitability of plant and insect hosts for herbivores, predators and parasites. Second,

Jared G. Ali jga8@psu.edu

C. L. Casteel ccasteel@ cornell.edu

K. E. Mauck

kerry.mauck@ucr.edu

1 Department of Entomology, The Pennsylvania State University, University Park, PA 16802, USA

2 Plant Pathology and Plant-Microbe Biology, School of Integrative Plant Science, Cornell University, Ithaca, NY 14850, USA

3 Department of Entomology, University of California, Riverside, Riverside, CA 92521, USA microorganisms can alter utilization of hosts by plants and insects by changing apparency or adding novel physiological functions (e.g. synthesis of amino acids) (Fig. 1). Indeed, a recent explosion of papers on plant-microbe-insect interactions demonstrate that suitability and utilization are often impacted by both individual microbes and microbial consortia, or "microbiomes." A term search including "microbiome" AND "plant" AND "insect" returned only 122 papers published prior to 1991. But in the years since Barbosa et al. (1991) was published, this field has flourished, with the same search returning 16,500 published papers between 1991 and 2020. Vector-borne microbes, such as viruses and phloemlimited bacteria, provide key examples. These biotrophic pathogens often cause drastic changes in plant chemistry that alter plant nutritional value, volatile profiles, and defenses, which have cascading effects on plant-insect interactions and even subsequent transmission by arthropod vectors (Cardoza et al. 2002; Cardoza and Tumlinson 2006; Shikano et al. 2017; Mauck et al. 2018; Bak et al. 2019; Patton et al. 2020). Similarly unique effects on plant chemical phenotypes and trophic interactions have also been documented for microbes that don't cause obvious pathology, such as phyllosphere- and rhizosphere-associated bacteria and fungi, as well as mycorrhizae, and fungal and bacterial endophytes (Pineda et al. 2010). For example, inoculation of tomato plants with Bacillus subtilis simultaneously alters jasmonic-acid (JA) mediated defenses and JA-independent terpenoid biosynthesis, reducing plant suitability and host finding cues for whiteflies (Bemisia tabaci) (Valenzuela-Soto et al. 2010).

More recently, studies have begun to explore the roles of insect-associated microorganisms in conferring expanded functions. Careful manipulative experiments are revealing that microbes associated with insect guts can aid in detoxifying plant chemical defenses and inhibiting the activity of enzymes that reduce digestion efficiency (reviewed in Mason et al. 2019). The effects of insect-associated bacteria in saliva and regurgitant can even extend outside the insect host; deposition of bacteria on food plants at wound sites can suppress plant 
Fig. 1 Conceptual framework modified from Barbosa, Krischik, and Jones, 1991. Microorganisms have two major impacts on plant and insect hosts and the interactions they share. First, microorganisms can change the suitability of plant and insect hosts for herbivores, predators and parasites. Second, microorganisms can alter utilization of hosts by plants and insects, by changing apparency or adding novel physiological functions

\section{Effect of Microbes on Insect-Plant Interactions}

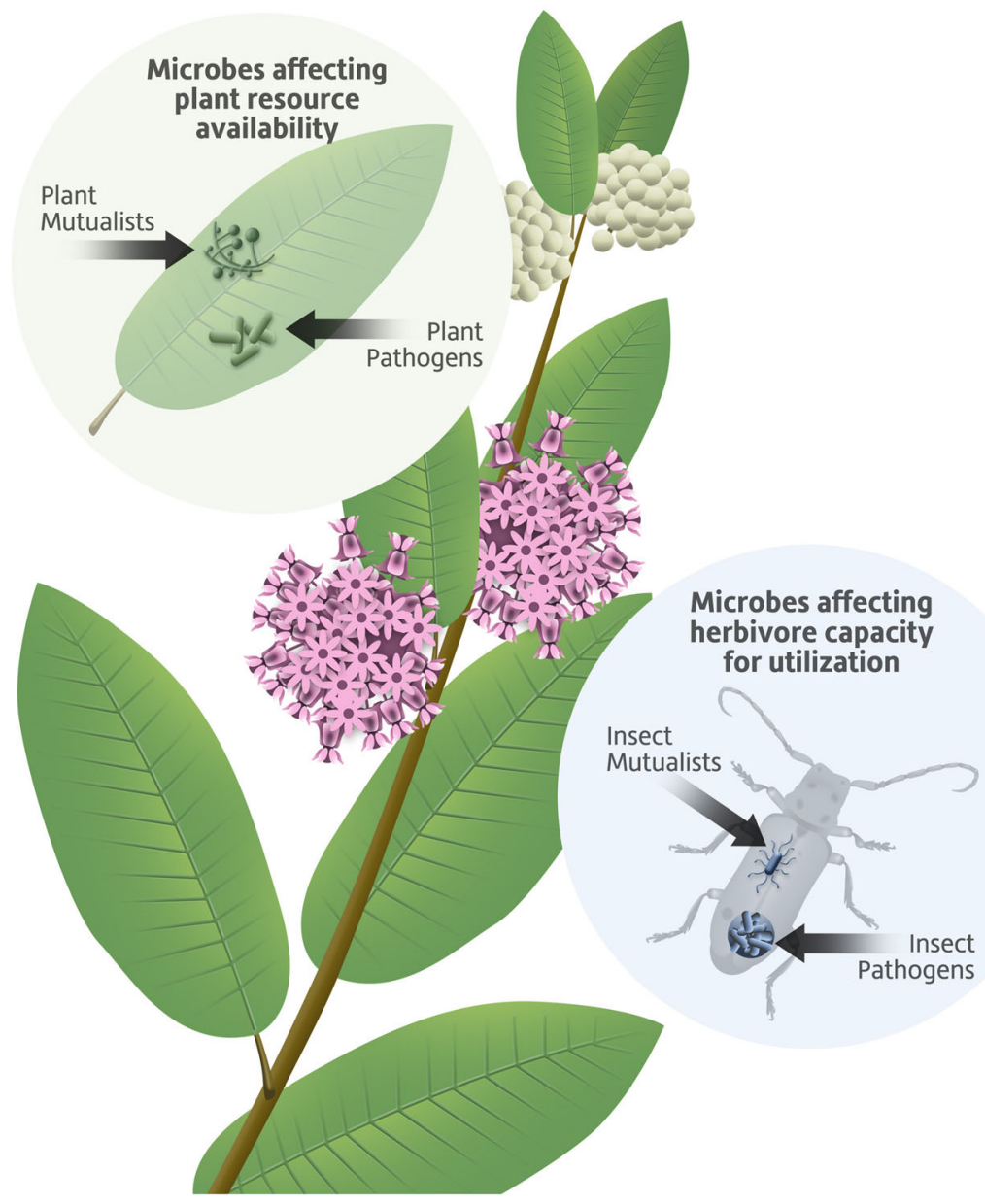

defenses against herbivores through antagonistic activation of anti-pathogen defense pathways (Chung et al. 2013; Wang et al. 2018). Progress in these research areas is changing our fundamental understanding of symbiotic associations and the ways we think about symbiosis in applied contexts. The chemical ecology of these interactions serves as both a unifying thread and a well-suited perspective to understand trends across systems.

In this special feature, we examine the range of symbiotic associations shared among microbes, herbivores and plants as well as the diversity of metabolic capabilities accomplished through these interactions. The collection of papers integrates studies across a taxonomic breadth of microbes, from viruses to fungi, to provide insight into the importance and evolutionary significance of small molecules as mediators of multitrophic interactions. The review and original research papers in this special issue address the role of plant pathogens in interactions between plants and insect vectors (Pradit et al. 2019; Gallinger and Gross 2020; Bera et al. 2020); the impacts of non-pathogenic plant- associated bacteria on plant growth (Ferreira et al. 2020), plantarthropod interactions (Karamanoli et al. 2020), and plantpollinator interactions (Rering et al. 2020); arbuscular mycorrhizal fungi and the role they play in different components of plant reproduction, such as pollen, pollen tube growth, and fertilization (Bennett and Meek 2020); the impacts of endophytic fungi on plant-insect interactions (Fuchs et al. 2020); the influence of soil microbiomes on plant chemistry (Huberty et al. 2020); the influence of plant chemistry on insect-fungi interactions (Salazar et al. 2020); the role of obligate insect symbionts in insect metabolomes (Ankrah et al. 2019); frugivorous insects and fruit associated microorganisms (Bueno et al. 2019; Baig et al. 2020); and microorganisms associated with insect guts (Adler et al. 2020; Mason 2020).

It is now well established that the microbe-free organism is a mythical creation of sterile laboratory environments, and that consideration of microbial players is essential, no matter how much we may choose to simplify systems for logistical reasons (Partida-Martínez and Heil 2011). Plant- and insect- 
associated microbes affect species interactions in biologically meaningful ways, with potential fitness consequences for all interacting partners. The rapid expansion and reduced costs of sequencing technologies have exponentially increased the diversity of microbes we can detect and quantify, without the need to be able to culture these organisms. However, the metabolites, pathways, and metabolic capabilities mediating these interactions are just beginning to be described and connected to the broader ecological framework in which microbial effects are well established. There is a clear need for greater integration of chemical ecology into microbiome research to facilitate this important work. The papers in this special issue address this need by revealing the different ways plants and insects interface with microbes through the lens of the molecules mediating these interactions. By exploring and discussing the roles of individual microbe species and microbiomes in driving ecological interactions, extending metabolisms, and influencing natural selection, the collected works in this issue will help the chemical ecology community continue to develop and test exciting new hypotheses about the molecules that connect plants, insects, and microbes.

\section{References}

Adler LS, Fowler AE, Malfi RL, Anderson PR, Coppinger LM, Deneen PM, Lopez S, Irwin RE, Farrell IW, Stevenson PC (2020) Assessing chemical mechanisms underlying the effects of sunflower pollen on a gut pathogen in bumble bees. J Chem Ecol. https://doi.org/10. 1007/s10886-020-01168-4

Ankrah NYD, Wilkes RA, Zhang FQ, Aristilde L, Douglas AE (2019) The metabolome of associations between xylem-feeding insects and their bacterial symbionts. J Chem Ecol. https://doi.org/10.1007/ s10886-019-01136-7

Baig F, Farnier K, Piper AM, Speight R, Cunningham JP (2020) Yeasts influence host selection and larval fitness in two frugivorous carpophilus beetle species. J Chem Ecol. https://doi.org/10.1007/ s10886-020-01167-5

Bak A, Patton MF, Perilla-Henao LM, Aegerter BJ, Casteel CL (2019) Ethylene signaling mediates potyvirus spread by aphid vectors. Oecologia 190:139-148. https://doi.org/10.1007/s00442-01904405-0

Barbosa P, Krischik VA, Jones CG (1991) Microbial Mediation of PlantHerbivore Interactions (Wiley)

Bennett AE, Meek HC (2020) The influence of arbuscular mycorrhizal fungi on plant reproduction. J Chem Ecol. https://doi.org/10.1007/ s10886-020-01192-4

Bera S, Blundell R, Liang D, Crowder DW, Casteel CL (2020) The oxylipin signaling pathway is required for increased aphid attraction and retention on virus-infected plants. J Chem Ecol. https://doi.org/ 10.1007/s10886-020-01157-7

Bueno E, Martin KR, Raguso RA, Mcmullen JG II, Hesler SP, Loeb GM, Douglas AE (2019) Response of wild spotted wing Drosophila (Drosophila suzukii) to microbial volatiles. J Chem Ecol. https:// doi.org/10.1007/s10886-019-01139-4

Cardoza YJ, Tumlinson JH (2006) Compatible and incompatible Xanthomonas infections differentially affect herbivore-induced volatile emission by pepper plants. J Chem Ecol 32:1755-1768. https:// doi.org/10.1007/s10886-006-9107-y
Cardoza YJ, Alborn HT, Tumlinson JH (2002) In vivo volatile emissions from peanut plants induced by simultaneous fungal infection and insect damage. J Chem Ecol 28:161-174

Chung SH, Rosa C, Scully ED, Peiffer M, Tooker JF, Hoover K, Luthe DS, Felton GW (2013) Herbivore exploits orally secreted bacteria to suppress plant defenses. Proc Natl Acad Sci U S A 110:1572815733. https://doi.org/10.1073/pnas.1308867110

Ferreira NP, Ximenez GR, Chiavelli LUR et al (2020) Acyl-homoserine lactone from plant-associated Pseudomonas sp. influences Solanum lycopersicum germination and root growth. J Chem Ecol. https://doi. org/10.1007/s10886-020-01186-2

Fuchs B, Kuhnert E, Krauss J (2020) Contrasting effects of grass - endophyte chemotypes on a tri-trophic cascade. J Chem Ecol 46:422429. https://doi.org/10.1007/s10886-020-01163-9

Gallinger J, Gross J (2020) Phloem metabolites of Prunus Sp. rather than infection with Candidatus Phytoplasma prunorum influence feeding behavior of Cacopsylla pruni nymphs. J Chem Ecol. https://doi.org/ 10.1007/s10886-020-01148-8

Gerardo NM, Altincicek B, Anselme C, Atamian H, Barribeau SM, de Vos M, Duncan EJ, Evans JD, Gabaldón T, Ghanim M, Heddi A, Kaloshian I, Latorre A, Moya A, Nakabachi A, Parker BJ, PérezBrocal V, Pignatelli M, Rahbé Y, Ramsey JS, Spragg CJ, Tamames J, Tamarit D, Tamborindeguy C, Vincent-Monegat C, Vilcinskas A (2010) Immunity and other defenses in pea aphids, Acyrthosiphon pisum. Genome Biol 11:R21. https://doi.org/10.1186/gb-2010-11$2-\mathrm{r} 21$

Gross J, Eben A, Müller I, Wensing A (2010) A well protected intruder: the effective antimicrobial defense of the invasive ladybird Harmonia axyridis. J Chem Ecol 36:1180-1188. https://doi.org/10. 1007/s10886-010-9867-2

Hansen AK, Pers D, Russell JA (2020) Chapter five - symbiotic solutions to nitrogen limitation and amino acid imbalance in insect diets. In: Oliver KM, Russell JA (eds) Advances in Insect Physiology. Academic Press, Cambridge, pp 161-205

Huberty M, Martis B, van Kampen J, Choi YH, Vrieling K, Klinkhamer PGL, Bezemer TM (2020) Soil inoculation alters leaf metabolic profiles in genetically identical plants. J Chem Ecol. https://doi. org/10.1007/s10886-020-01156-8

Karamanoli K, Kokalas V, Koveos DS, Junker RR, Farré-Armengol G (2020) Bacteria affect plant-mite interactions via altered scent emissions. J Chem Ecol. https://doi.org/10.1007/s10886-020-01147-9

Mason CJ (2020) Complex relationships at the intersection of insect gut microbiomes and plant defenses. J Chem Ecol. https://doi.org/10. 1007/s10886-020-01187-1

Mason CJ, Jones AG, Felton GW (2019) Co-option of microbial associates by insects and their impact on plant-folivore interactions. Plant Cell Environ 42:1078-1086

Mauck KE, Chesnais Q, Shapiro LR (2018) Evolutionary determinants of host and vector manipulation by plant viruses. Adv Virus Res 101: 189-250. https://doi.org/10.1016/bs.aivir.2018.02.007

Partida-Martínez LP, Heil M (2011) The microbe-free plant: fact or artifact? Front Plant Sci 2

Patton MF, BakA SJM, Heck ML, Casteel CL (2020) A Polerovirus, potato leafroll virus, alters plant-vector interactions using three viral proteins. Plant Cell Environ 43:387-399. https://doi.org/10.1111/ pce. 13684

Pineda A, Zheng S-J, van Loon JJA, Pieterse CMJ, Dicke M (2010) Helping plants to deal with insects: the role of beneficial soilborne microbes. Trends Plant Sci 15:507-514. https://doi.org/10. 1016/j.tplants.2010.05.007

Pradit N, Mescher MC, De Moraes CM, Rodriguez-Saona C (2019) Phytoplasma infection of cranberry affects development and oviposition, but not host-plant selection, of the insect vector Limotettix vaccinii. J Chem Ecol. https://doi.org/10.1007/s10886-019-01137-6

Rering CC, Vannette RL, Schaeffer RN, Beck JJ (2020) Microbial cooccurrence in floral nectar affects metabolites and attractiveness to a 
generalist pollinator. J Chem Ecol. https://doi.org/10.1007/s10886020-01169-3

Salazar LC, Ortiz-Reyes A, Rosero DM, Lobo-Echeverri T (2020) Dillapiole in Piper holtonii as an inhibitor of the symbiotic fungus Leucoagaricus gongylophorus of leaf-cutting ants. J Chem Ecol. https://doi.org/10.1007/s10886-020-01170-w

Shikano I, Rosa C, Tan C-W, Felton GW (2017) TritrophiciInteractions: microbe-mediated plant effects on insect herbivores. Annu Rev Phytopathol 55:313-331. https://doi.org/10.1146/annurev-phyto080516-035319
Valenzuela-Soto JH, Estrada-Hernández MG, Ibarra-Laclette E, DélanoFrier JP (2010) Inoculation of tomato plants (Solanum lycopersicum) with growth-promoting Bacillus subtilis retards whitefly Bemisia tabaci development. Planta 231:397-410. https:// doi.org/10.1007/s00425-009-1061-9

Wang J, Yang M, Song Y, Acevedo FE, Hoover K, Zeng R, Felton GW (2018) Gut-associated bacteria of Helicoverpa zea indirectly trigger plant defenses in maize. J Chem Ecol 44:690-699. https://doi.org/ 10.1007/s10886-018-0970-0 